\title{
Imagens da infância na Atenas clássica
}

\author{
Images of childhood in Classical Athens
}

\author{
Alexandre Santos de Moraes* \\ Fábio de Souza Lessa**
}

\begin{abstract}
Resumo: Neste texto, propomos uma reflexão sobre o espaço ocupado pela infância na sociedade ateniense do período clássico (séculos V e IV a.C.). Partiremos da dificuldade de demarcação e conceitualização dessa faixa etária entre os helenos e da sua visão social negativa para entender a importância das crianças em Atenas, para além da perpetuação do grupo doméstico e da pólis, pensando nas suas relações de afeto familiar e na sua socialização por meio de jogos e de brincadeiras infantis. As imagens áticas pintadas em suporte cerâmico serão a documentação essencial para o presente estudo.
\end{abstract}

\begin{abstract}
In this article, we aim to ponder on the role of infancy in the Athenian society in the scope of the classical period (5th and 4th centuries B.C.). We start with the difficulty of definition and conceptualization of this age range among the Hellenes, in addition to their negative social perspective about them, in order to understand the importance of children in Athens, far beyond the perpetuation of the domestic group and of the polis. To do so, we intend to take also into account their affective relations in the family's realm as well as their socialization by means of games and children's play. The Attic images painted on ceramic supports will be the major type of document used in this study.
\end{abstract}

\author{
Palavras-chave: \\ Infância. \\ Cerâmica ática. \\ Atenas Clássica. \\ Afeto familiar.
}

\section{Keywords:}

Childhood.

Attic pottery. Classical Athens. Family affection.
Recebido em: 30/11/2020

Aprovado em: 09/01/2021

\footnotetext{
* Professor Adjunto de História Antiga do Instituto de História e do Programa de Pós-Graduação em História da Universidade Federal Fluminense. Membro do Núcleo de Representações e de Imagens da Antiguidade (NEREIDA/UFF) e colaborador do Laboratório de História Antiga (LHIA/UFRJ).

** Professor Titular de História Antiga do Instituto de História e dos Programas de Pós-Graduação em História Comparada e de Letras Clássicas da Universidade Federal do Rio de Janeiro. Membro do Laboratório de História Antiga da UFRJ e membro colaborador do Centro de Estudos Clássicos e Humanísticos da Universidade de Coimbra.
} 


\section{Introdução}

infância e a juventude receberam grande atenção acadêmica a partir do século
$X X .{ }^{1}$ Nas Ciências Humanas e Sociais, adotou-se como perspectiva o fato de que
as idades da vida são eventos biológicos socialmente refletidos (BOURDIEU, 2008, p. 113; DEBERT, 2007, p. 51; EISENSTADT, 1976, p. 1; GROPPO, 2000, p. 8; MORAES, 2013). Essa noção esteve fortemente influenciada por clássicos como Coming of age in Samoa (1928), de Margaret Mead, e The sexual life of savages in NorthWestern Melanesia, de Bronislaw Malinowski (1929). Os Estudos Clássicos não ignoraram essa tendência. Em 1933, Clarence Allen Forbes publicou Neoi: a contribution to the study of Greek associations; em 1936, Werner Jaeger lançou o bastante examinado Paideia, die formung des griechischen menschen; em 1939, Henri Jeanmaire apresentou seu Couroi et courètes: essai sur l'éducation spartiate et sur les rites d'adolescence dans l'Antiquité Hellénique. A questão da iconografia da infância foi tratada no livro Child life in Greek Art (1932), de Anita Klein, um catálogo relativamente extenso de imagens sobre as crianças. As idades da vida passam a ser, portanto, objeto de preocupação acurada dos pesquisadores.

Esse impulso, sobretudo ligado às análises das primeiras fases da vida, recrudesce por volta de meados do século XX. Trata-se, portanto, de um tema extremamente recente e que acompanha, por óbvio, as condições materiais que o tornaram objeto de interesse. Na década de 1990, Mark Golden (1993) oferece uma obra de referência sobre o assunto, que acaba por inspirar vários especialistas a se debruçar sobre a infância no mundo antigo (FERREIRA, 2010, p. 139). Sua proposta foi investigar a vida pública e privada das crianças atenienses de 500 a 300 a.C. (GOLDEN, 1993, p. 13).

Tendência similar é percebida com o advento da juventude sob novas lentes de observação. Jon Savage (2009) observa que os norte-americanos popularizaram a palavra teenager precisamente nessa época. Segundo o autor, foi um termo de marketing usado por publicitários e fabricantes para estimular novas práticas de consumo. Ainda de acordo com o autor (SAVAGE, 2009, p. 11), "o fato de que, pela primeira vez, os jovens se tornaram um público-alvo também significava que eles tinham se transformado num grupo etário específico com rituais, direitos e exigências próprios". Os desenvolvimentos ulteriores, sobretudo na historiografia, são bastante conhecidos, a recordar principalmente os debates estimulados pela obra L'enfant et le vie familiale sous l'Ancien Régime (1973), de Philippe Ariès.

\footnotetext{
${ }^{1}$ Uma boa síntese desse debate pode ser consultada no capítulo de Luísa de Nazaré Ferreira (2010, p. 137-142)
} 
Não é fortuito que esses temas tenham assumido preeminência nos períodos posteriores às Grandes Guerras do século XX è̀s experiências de crise que se desdobraram a partir delas:

\begin{abstract}
Na medida em que existe o desejo de adotar uma nova orientação, isso terá de fazer-se através da juventude. As gerações mais velhas ou intermediárias podem ser capazes de prever a natureza das mudanças futuras e sua imaginação criadora pode ser empregada para formular novas políticas; mas a nova vida será vivida apenas pelas gerações mais jovens. Estas viverão os novos valores que os velhos professam somente em teoria. Sendo assim, a função da juventude é a de um agente revitalizador. Trata-se de uma espécie de reserva que se revela apenas se tal revitalização for desejada (MANNHEIM, 1976, p. 92-93).
\end{abstract}

Nesse sentido, Karl Mannheim (1976, p. 92-93) observa oportunamente que a juventude emergia então como uma categoria etária de cunho revitalizador, na qual era depositada a expectativa por uma mudança política no então instável cenário mundial. Já Giovanni Levi e Jean-Claude Schmitt (1996, p. 7-9), em meados dos anos 1990, apontaram a dificuldade para se definir juventude e viram esta fase da vida também como resultante de uma construção sociocultural. Entenderam a idade como portadora de uma característica específica: é uma condição transitória. Em síntese: "os indivíduos não pertencem a grupos etários, eles os atravessam". Ora, diante das crises que se anunciam nesse início de século XXI, sobretudo as que envolvem nossa relação destrutiva com o meio ambiente, a popularização do pensamento de nítidos contornos fascistas, o fracasso da promessa de que a globalização solaparia os nacionalismos conservadores e, não menos importante, a crise sanitária exposta pela disseminação planetária do novo coronavírus, as preocupações com a infância e juventude parecem gozar de terreno favorável para sua renovação e a Antiguidade, mais uma vez, pode e deve ser convidada a participar das reflexões acerca de nossos dilemas do presente da vida social.

Neste texto, nos propomos a analisar o caráter de liminaridade que caracteriza não tão somente a juventude, mas também a infância. Essa é uma fase, na contemporaneidade e na Antiguidade, em que a presença feminina/materna se faz muito presente. ${ }^{2} \mathrm{Na}$ Grécia Antiga, o acompanhamento das crianças comumente ficou entregue às mulheres do oikos: mãe, avó, amas. O que intencionamos estudar é, num primeiro momento, esse mundo da afetividade feminina para com a infância; já num segundo, o próprio universo das crianças helênicas. As imagens áticas pintadas em suporte cerâmico do período clássico

\footnotetext{
2 Segundo Margarida Moreno Conde (2015, p. 38), as crianças do sexo feminino permaneciam no gineceu depois dos primeiros sete anos de vida, enquanto os meninos passavam, após esse período, a desfrutar da figura do pedagogo no oikos e somente depois eram enviados à escola. Já os heróis tinham a sua infância desenrolada fora da casa paterna (SCHMITT PANTEL, 2019, p. 238).
} 
(séculos V e IV a.C.) constituirão o corpus documental prioritário da pesquisa, mas sempre dialogando com os textos literários gregos.

\section{Crianças gregas: breve reflexão conceitual}

Refletir sobre o problema da demarcação e conceituação das faixas etárias na Grécia antiga, em especial acerca da infância, nos remete a algumas imprecisões. Em primeiro lugar, porque a contagem cronológica do tempo de vida não parece ter sido prática generalizada na Antiguidade. ${ }^{3}$ Em segundo lugar, porque a reflexão sobre o tempo de vida e suas respectivas etapas não pode ser dissociada, pelo menos no caso grego, das visões mais gerais que os antigos possuíam a respeito do tempo propriamente dito e dos ritmos da natureza. Em terceiro lugar, porque há evidências de que as mudanças no corpo eram tomadas como símbolos diacríticos mais importantes do que costumamos admitir em termos hodiernos. ${ }^{4}$

Não menos relevante é o fato de que a língua grega não dispunha de vocábulos cujos sentidos se aproximassem de "infância" ou "idade adulta", por exemplo. Para designar "crianças", o vocábulo đaîs era um dos mais frequentemente utilizados. Seu sentido está associado a uma ideia de parentesco filial e, sendo comum aos dois gêneros, costuma ser vertido para "filho" ou "filha". É frequentemente evocado para se referir à genealogia de determinada personagem ou sujeito. Sentido similar se aplica ao vocábulo tékvov, também traduzível por criança (BAILLY, 2000, p. 1908), mas frequentemente vertido por "filho" ou "filha"; é o que se observa, por exemplo, em Heródoto, quando Sólon narra ao rei Creso a felicidade do ateniense Telo, que tinha "dois filhos belos e bons" [ $\pi \alpha \hat{\delta} \delta \varepsilon \varsigma$

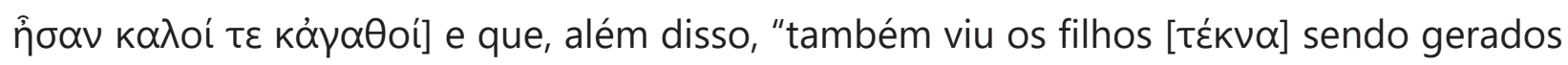
por todos eles" (HERÓDOTO. Histórias, I, 30). Em ambos os casos, as palavras também podem qualificar sujeitos em "idade adulta" que costumam ter relações afetivas com o interlocutor, mas seu uso mais comum é para se referir às crianças.

\footnotetext{
${ }^{3}$ Segundo Meyer Fortes (1986, p. 99), "reveste-se de significado quando o quadro político e legal assume preeminência sobre a família e o parentesco na determinação da cidadania". Essa questão é utilizada por Thomas M. Falkner (1990) para justificar aquela que parece ser a primeira tentativa de sistematizar a vida em fases na Grécia antiga. Trata-se de

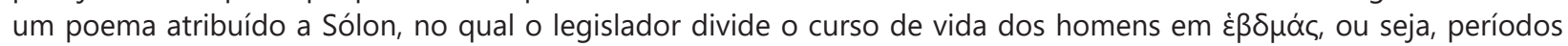
de sete anos (Solon. frag. 27 West). Segundo o autor, a necessidade de organizar a vida dos cidadãos com base em princípios impessoais veio à tona com a reorganização social na Atenas do século VI a.C., "de modo que o poema reflete a crescente importância da idade cronológica na vida social ateniense", apesar do fato de que o modelo de Sólon parece antes uma "criação artística do que uma descoberta de ordem natural" (FALKER, 1990, p. 7-8).

${ }^{4}$ Vê-se, por exemplo, a questão do cabelo, tomado como referência inúmeras vezes para definir as posições etárias dos sujeitos, em função de seu tamanho, aspecto e coloração. Como observou Irwin (1990, p. 210), "através da cor, tamanho e maneira com que o cabelo era usado, os poetas gregos retrataram juventude ou velhice, beleza ou feiúra, nobreza ou baixeza".
} 
Não menos evidente é o sentido da palavra vńmı de "ser criança" em função da fala: ainda que a etimologia não esteja bem assentada nos dicionários, ${ }^{5}$ o estudo de Susan Edmunds (1990, p. 10), sobretudo a partir das análises que fez da épica homérica, demonstrou que "quando alguém é nēpios é paîs hōs, 'como uma criança', ao passo que quando alguém é èpios, é patēr hōs, 'como um pai'" (EDMUNDS, 1990, p. 10). Ainda de acordo com a autora, "o personagem caracterizado como n̈mios é maduro, dá bons conselhos, entende de justiça e promove a coesão social; o vńmı contudo, é associado a um mundo perigoso e fragmentado, ao risco de tornar-se um órfão, alijado do mundo social, ou incapaz de observar leis de hospitalidade, estando assim fora da rede de conexões humanas" (EDMUNDS, 1990, p. 98). Curiosamente, a palavra vńmıৎৎ é a que mais se aproxima do sentido latino de infantia, "que significava na origem 'incapacidade de falar' e foi depois empregue para designar o período de vida até aos setes anos de idade" (FERREIRA, 2010, p. 142-143). Há pelo menos dois outros qualificativos frequentemente usados para definir crianças quando associados a sujeitos: TUTӨóc, "pequenino", "de baixa estatura", e véoc, "novo", "novidade".

Aparentemente, poderíamos observar, por meio do contexto sociodiscursivo de uso dessas palavras, alguma definição possível acerca das diferenças e períodos próprios a cada fase da vida no mundo grego. Porém, o que predomina entre os especialistas é a não concordância quanto à designação e mesmo a percepção de fronteiras para cada uma das etapas etárias gregas (GOLDEN, 1993, p. 12-22; SOARES, 2011, p. 13-28). Em outras palavras, a infância, assim como a velhice, como conceito, se encontrava praticamente ausente dos textos antigos (CONDE, 2015, p. 41), o que não significa que as crianças não foram objeto de atenção e que a documentação antiga não cuidou de oferecer alguns pontos de vista demasiado significativos sobre as experiências desses primeiros anos da vida, sobretudo no marco de suas relações familiares.

\footnotetext{
${ }^{5}$ Esta etimologia de vท́тıঃৎ não é consensual entre os gramáticos. O dicionário de Bailly (2000, p. 1326), por exemplo, considera que a origem da palavra é obscura. O léxico de Liddell \& Scott (1992) também não afirma que o vocábulo

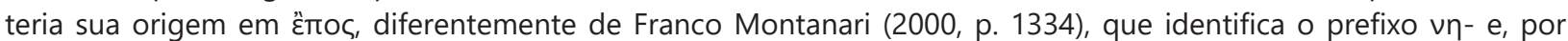
isso, considera "que não fala" como um dos significados possíveis. O dicionário etimológico de Robert Beekes (2010), retomando as proposições de Lacroix (1937, p. 261), também considera como válida a assunção de vn- como um prefixo de negação. Chantraine (1983, p. 723), a seu turno, julga que o sentido "que ainda não fala" não se apoia em nenhuma tradição antiga, de modo que, para o autor, o sentido principal é "de pouca idade".
} 


\title{
Afetos familiares: mães e filhos em imagens áticas
}

\author{
Ademais, nossa vida infantil não é desejável, \\ e ninguém no seu juízo se disporia a suportar o seu retorno \\ (Aristóteles, Ethica Eudemia, 1215b).
}

Aristóteles, na epígrafe acima, deixa claro o quanto a infância é uma fase delicada na vida dos gregos antigos. Ele prossegue (1219b) afirmando que "não existe felicidade infantil". Talvez esse quadro de "infelicidade" estivesse ligado à ideia de que as crianças, de modo geral, apresentavam uma carência de coragem que as distinguia dos adultos (SOARES, 2011, p. 45-6). Ou, ainda, à visão predominante entre os pesquisadores que se dedicam ao estudo da infância na Grécia Antiga de que essa faixa etária era formada por pessoas mentalmente incapazes (GOLDEN, 1993, p. 5; SOARES, 2011, p. 51-2). Seguindo essa lógica, as crianças, além de incapazes, poderiam ainda assumir um papel passivo na história (LEVI; SCHMITT, 1996, p. 16).

Tudo o que vimos até o presente momento nos direciona para refletir acerca do estatuto social da criança, sempre vista como marginal pelos helenos e, por isso, equiparada à mulher e ao escravo (GOLDEN, 1993, p. 7; FERREIRA, 2011, p. 61, 72). Essa relação entre criança e mulher foi eternizada por Aristóteles (Politica, 1260a) ao afirmar que "é aproximadamente a mesma a dificuldade levantada acerca da mulher e da criança; têm elas também qualidades, e deve a mulher ser moderada, corajosa e justa, e pode uma criança ser chamada de imoderada ou moderada, ou não?".

Se comparadas aos jovens e aos adultos, ${ }^{6}$ a criança é considerada um ser imperfeito e inferior; física, intelectual e eticamente (FERREIRA, 2010, p. 145-7; GOLDEN, 1993, p. 7). ${ }^{7}$ No fundo, a criança não se encontra completamente desenvolvida (Arist., Pol., 1260a), o que fez com que a cultura grega não lhe reconhecesse como portadora de uma personalidade autônoma. Lançando mão de referências da llíada (IV, v. 2) e da Odisseia (XI, v. 603), que associam juventude à deusa Hebe, Mark Golden (1993, p. 4) afirma que a sociedade grega não parece ter sentido a nostalgia da infância, preferindo exaltar a juventude e os belos corpos. Porém, não podemos deixar de lembrar que, ao contrário da mulher e dos escravos, a condição inerente à infância é temporária (FERREIRA, 2010, p. 147).

Assim como Pauline Schmitt Pantel (2019), Luísa Ferreira (2011, p. 59-60, 66, 81; 2010, p. 139, 146) já havia atentado para o fato de que os documentos literários, epigráficos

\footnotetext{
${ }^{6}$ Vale reforçar que a juventude era vista como o período da vida enaltecido pelos gregos antigos como o momento mais perfeito e o mais efêmero da existência (CONDE, 2015, p. 31).

7 Sobre essa questão da inferioridade da criança e de sua associação às mulheres e aos escravos, ver: Platão, República, 431c.
} 
e a cultura material disponíveis podem ainda não permitir um conhecimento completo e satisfatório sobre o universo infantil no mundo antigo. Porém, a helenista não deixa de ressaltar que informações significativas acerca das crianças gregas provêm do repertório imagético pintado na cerâmica ática dos períodos arcaico e clássico. Predominam, nesse corpus imagético, cenas de entretenimento e de demais atividades cotidianas. Apesar de as crianças não terem sido completamente ignoradas, a literatura grega tendeu a silenciar a infância, se compararmos com as referências sobre a juventude e a velhice.

Uma simples busca na base de dados Beazley Archive atesta a importância da documentação imagética para o estudo da infância grega. Ao digitarmos a palavra inglesa child, nos deparamos com um universo de 506 vasos áticos figurados. É claro que o estado de conservação das cerâmicas e as temáticas nelas pintadas são variáveis.

Desse grande universo de vasos com temática infantil, selecionamos apenas cinco para análise neste texto: uma amphora, ${ }^{8}$ um lékythos, ${ }^{9}$ uma hýdria ${ }^{10}$ e dois choes. ${ }^{11}$ Todos esses vasos pertencem ao estilo de figuras vermelhas. ${ }^{12}$ Tal seleção não foi aleatória, pois sabemos que o corpus de figuras vermelhas era mais rico na representação da infância e as suas formas de figuração também variaram bastante, diferentemente da situação dos vasos de figuras negras (FERREIRA, 2011, p. 72-5).

O nosso corpus imagético para esse texto privilegia duas temáticas que predominam nas cerâmicas de figuras vermelhas e que adquiriram cada vez mais importância no decorrer do século V a.C., a saber: os afetos familiares e as brincadeiras infantis. ${ }^{13}$ Segundo Luísa Ferreira (2011, p. 69, 76), nesse momento, as cenas de gineceu tornaram-se muito mais frequentes e as crianças passam a estar cada vez mais presentes ou até mesmo a constituírem o tema principal das imagens. Continua a autora a argumentar que os artistas áticos representaram todas as experiências que preenchiam o cotidiano de uma criança; as relações familiares e sociais, a educação e as brincadeiras. ${ }^{14}$ Reforçamos que o afeto, presente na relação entre mães e filhos funciona como veículo para estabelecer uma ligação emocional estruturante no momento de formação do caráter do indivíduo (SOARES, 2011, p. 109-10).

\footnotetext{
${ }^{8}$ Vaso usado para líquidos e sólidos. Servia para armazenar e transportar vinho, óleo e demais artigos.

${ }^{9}$ Vaso usado para óleos e unguentos. Também servia como oferenda para o morto.

${ }^{10}$ Vaso usado para o armazenamento e o transporte de água da fonte.

${ }^{11}$ Vaso semelhante a uma oinochoe, destinado a medir o vinho no festival das Antestérias. Também servia para as brincadeiras infantis no festival.

${ }^{12}$ Apresenta os elementos da decoração em tom claro sobre fundo escuro, já que o estilo chamado de figuras negras se constitui pela apresentação dos elementos da decoração em tom escuro sobre fundo claro.

${ }^{13}$ Cenas de gravidez e de parto são temas raros na arte grega, com exceção das cenas de nascimento de personagens míticos, como o de Atena (CONDE, 2015, p. 32).

${ }^{14}$ Julgamos necessário ressaltar que Platão, na República (378c-d), condena o fato de se contarem às crianças narrativas que ele considerava como não pertinentes.
} 
Recorrendo ao trabalho clássico de Philippe Ariès (2006, p. xi), observamos a sua afirmação de que a partir do fim do século XVII é que a família se tornou o lugar de uma afeição necessária entre cônjuges e entre pais e filhos, algo que não acontecia anteriormente. Porém, o convívio diário entre crianças, mães e amas gregas, isto é, a intimidade do gineceu, já havia despertado o interesse dos pintores atenienses. ${ }^{15}$

No tocante à arte do pintor, Alain Schnapp (1996, p. 35) salienta que esta consiste em servir-se da observação para ultrapassar a singularidade dos seres, chegando à qualidade estética que transcende cada detalhe para integrá-lo na unidade da obra, algo que guarda proximidade com o que Jean-Pierre Vernant (1991, p. 47) já havia mencionado. Para o helenista, qualquer estudo iconográfico deve tratar de explorar o entrelaçamento de signos e estabelecer a combinatória dos elementos significativos da imagem, de seu relacionamento no interior das diversas séries homogêneas, em função da geografia, da natureza dos objetos e da temática.

Outra questão no que se refere à representação infantil e que nos permite retornar ao debate acerca da concepção de inferioridade das crianças frente aos adultos é o fato de serem comumente representadas como um adulto em tamanho diminuto, como uma versão em miniatura. Assim sendo, "a criança é um ser imperfeito, incompleto, em comparação com o adulto" e a sua distinção de um adulto nas imagens se dá pela estatura menor (FERREIRA, 2010, p. 145; 2011, p. 61, 67, 75). Essa questão também não escapou à análise de Philippe Ariès (2006, p. xiii, 17-18). Segundo o autor, até o fim do século XIII não existiam crianças caracterizadas por uma expressão particular, e sim homens de tamanho reduzido. ${ }^{16}$

Nesta seção do presente texto nos dedicaremos a analisar cenas referentes aos afetos desenvolvidos entre mães e filhos. Segundo Anita Klein (1932, p. 1), a vida da criança grega nos momentos iniciais de sua existência não pode ser observada sem, ao mesmo tempo, vê-la em suas interações com a mãe ou com a ama. Munidos de tais informações, passemos à interpretação da primeira imagem (Figura 1), pintada em uma amphora datada de 470-60 a.C. e atribuída ao pintor Bóreas. ${ }^{17}$

\footnotetext{
${ }^{15}$ Antes de passarmos propriamente para a análise das imagens, convém enfatizar que elas não constituem ilustrações de textos escritos. Pelo contrário, "elas criam as suas próprias composições, levando em conta os constrangimentos do espaço disponível e talvez também o gosto dos consumidores desses objetos" (SCHMITT PANTEL, 2019, p. 196).

${ }^{16}$ Ariès (2006, p. 18) sublinha que essa recusa em aceitar, na arte, a morfologia infantil é encontrada na maioria das sociedades arcaicas, como a grega.

17 O método semiótico proposto por Claude Calame (1986) para as imagens pressupõe:

$1^{\circ}$. verificar a posição espacial dos personagens, dos objetos e dos ornamentos em cena;

$2^{\circ}$. fazer um levantamento dos adereços, mobiliário, vestuários e os gestos, estabelecendo um repertório dos signos; $3^{\circ}$. observar os jogos de olhares dos personagens.

3.1. perfil: o receptor da mensagem do vaso não está sendo convidado a participar da ação. Neste caso, o personagem deve servir como exemplo para o comportamento do receptor;
} 
Figura 1 - Amphora atribuída ao pintor Bóreas, datada de 470-60 a.C.

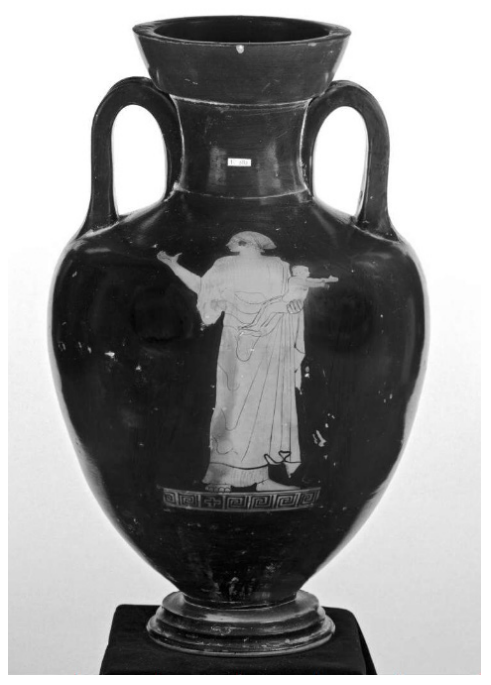

Localização: The British Museum - inv. E282, Temática: mãe e filho, Proveniência: Vulci, Etrúria, Forma: amphora, Estilo: Figuras Vermelhas, Pintor: Bóreas, Data: 470-60 a.C. (British Museum), 500-450 a.C. (Brazley); Indicação Bibliográfica: FERREIRA, 2011, fig. 2; www.beazley..ox.ac.uk/index.htm (vaso number 206109 consultado em outubro de 2020); https://www.britishmuseum.org/collection/object/G_1843-1103-33. Acesso em: outubro de 2020.

No centro da imagem, temos uma mulher, tudo indica que a mãe da criança, vestida com um chitón jônico, manto, colar, brincos e cabelos envoltos por um tecido. Esses signos denotam ser, para as imagens áticas, a personagem uma esposa legítima e bemnascida (LESSA, 2010, p, 37). ${ }^{18}$ A personagem se encontra de pé e de frente, mas com o pé esquerdo voltado para a direita; ela olha para a esquerda, levantando a mão direita com um gesto de aceno também em direção à esquerda. Se levarmos em consideração a outra face representada, podemos pensar em uma cena típica de partida, na qual contamos com a esposa, o filho e o marido guerreiro. ${ }^{19}$ Talvez o gesto da personagem feminina - o olhar para a esquerda e o levantar a mão direita com um gesto de aceno também em direção à esquerda - possa significar um gesto de unir as duas cenas, formando uma enunciação holística do vaso.

\footnotetext{
3.2. três quartos: o personagem que olha tanto para o interior da cena quanto para o receptor está possibilitando, a este último, participar da cena;

3.3. frontal: personagem convida o receptor a participar da ação representada.

${ }^{18} \mathrm{Em}$ trabalho anterior, verificamos os signos recorrentes que identificavam uma personagem feminina figurada em uma cerâmica ática como esposa bem-nascida. Ver o quadro síntese que se encontra no livro Mulheres de Atenas: Mélissa do gineceu à agorá (LESSA, 2010, p. 37).

${ }^{19} \mathrm{Na}$ face oposta, temos um guerreiro, barbudo, com cabelo comprido, cachos pardos caindo ao lado das orelhas, manto pendurado no braço esquerdo, capacete inclinado para trás, e um grande escudo com dispositivo de cobra arqueando para a esquerda. Ele está de pé à esquerda, segurando a lança vertical na mão direita.
} 
Há um consenso entre os especialistas de que, nas cenas semelhantes às que estamos analisando, o esquema cênico é regularmente composto da mãe em pé (Figuras 1 e 2) ou sentada (Figura 3), amamentando a criança ou simplesmente a segurando no braço esquerdo enquanto o bebê vira o rosto em direção ao dela (KLEIN, 1932, p. 2). No caso da imagem que estamos estudando, a mãe segura o bebê, que se encontra nu em seu braço esquerdo, que se senta à esquerda, mas se vira para a direita e estende ambos os braços, como se fosse para o guerreiro presente na outra face. A criança usa sobre o ombro esquerdo um cinto cruzado infantil, um amuleto de proteção. Deve-se destacar o cuidado do pintor com as formas do corpo da criança e em destacar o sexo masculino. Claramente, a esposa havia cumprido a sua função mais fundamental na sociedade grega: a concepção de filhos do sexo masculino.

Interessante é trazer para a discussão as colocações de Timothy McNiven (2007, p. 85) acerca da linguagem não-verbal das crianças na imagética ática. De acordo com o autor, os pintores atenienses desenvolveram uma sofisticada linguagem dos gestos para permitir a comunicação dos seus personagens. Diante da ausência de expressões faciais, os gestos adquirem uma dimensão econômica e efetiva para mostrar graficamente as reações de cada personagem em cena e para indicar a sua comunicação entre eles. 0 aprendizado da linguagem não-verbal se inicia antes mesmo de as crianças começarem a falar e se dá pela imitação espontânea ou ensinada pelos mais velhos. Vale frisar que o mesmo processo é pertinente para o aprendizado da fala. Assim como acontece no caso da linguagem verbal, o processo de aprendizagem não-verbal joga um papel na socialização das crianças, ajudando-as a se encaixarem na sociedade.

A próxima imagem (Figura 2) apresenta elementos cênicos muito semelhantes a essa primeira. De imediato, elas têm em comum o que poderíamos chamar de transposição do esquema iconográfico da kourotrophoi, "a que nutre, a criadora de jovens" (FERREIRA, 2011 , p. 63,$76 ; 2010$, p. 141). ${ }^{20}$ Nessas cenas, contamos com a representação da criança no colo da mãe ou da ama.

Se na amphora temos a integração da kourotróphos em uma cena familiar de partida de um guerreiro, no lékythos atribuído por Beazley ao pintor Pistóxeno, a sua integração acontece em uma cena típica de interior de uma casa, haja vista o espelho pendurado na parede e a banqueta, ambos posicionados atrás da personagem.

${ }^{20}$ Na Odisseia (IX, v. 27), o termo faz referência à terra de Odisseu: "É uma ilha áspera, mas boa criadora de mancebos (kourotróphos)". 
Figura 2 - Lékythos atribuído a Pistóxenos, datado de 475 a 425 a.C.

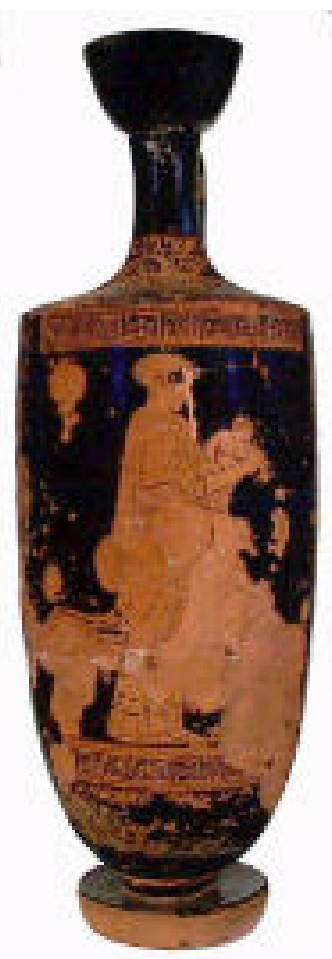

Localização: Ashmolean Museum (Oxford) - inv. V320, Temática: mãe e filho, Proveniência: não fornecida, Forma: lékythos, Estilo: Figuras Vermelhas, Pintor: atribuído a Pistóxenos, Data: 475 a 425 a.C.; Indicação Bibliográfica: FERREIRA, 2011, p. 76; www.beazley..ox.ac.uk/index.htm (vaso number 211374. Acesso em: outubro de 2020.

Assim como na imagem anterior, temos, nesse lékythos, uma personagem feminina no centro da cena, ricamente adornada e com os cabelos envoltos por um tecido. Ela possui, apoiado sobre o seu braço esquerdo, uma criança, possivelmente um menino. $O$ corpo da criança é bem delineado, destacando os músculos do seu peito. Embora seja um bebê com um olhar muito vivo, sua cabeça lembra a de um adulto (FERREIRA, 2011, p. 76). Talvez possamos retornar à questão já discutida acerca da representação das crianças como adultos em tamanho diminuto.

Ao retratar a mãe mantendo a criança sobre o seu braço esquerdo enquanto sua mão direita segura o braço esquerdo da criança, a cena nos possibilita perceber a curiosidade, que é uma característica expressiva das crianças que começam a descobrir o seu entorno (FERREIRA, 2011, p. 76).

Essa imagem, assim como a próxima (Figura 3), revela a presença de gestos que codificam a relação mais próxima entre pais e filhos. Essas imagens podem até ser representações particularmente escassas na cerâmica grega, mas em todas elas encontrase presente certa ternura, como as cenas no interior do oikos (CONDE, 2015, p. 37). 
Cumpre observar, no entanto, que o laço estreito que une mãe e filhos é sugerido de várias formas pelos artistas gregos (KLEIN, 1932, p. 6-7). Uma delas é a figurada na hýdria abaixo, datada entre os anos de 450 a 400 a.C., e atribuída ao pintor do Polygnotan Circle.

Figura 3 - Hýdria, de Polygnotan Circle, datada de 450-400 a.C.

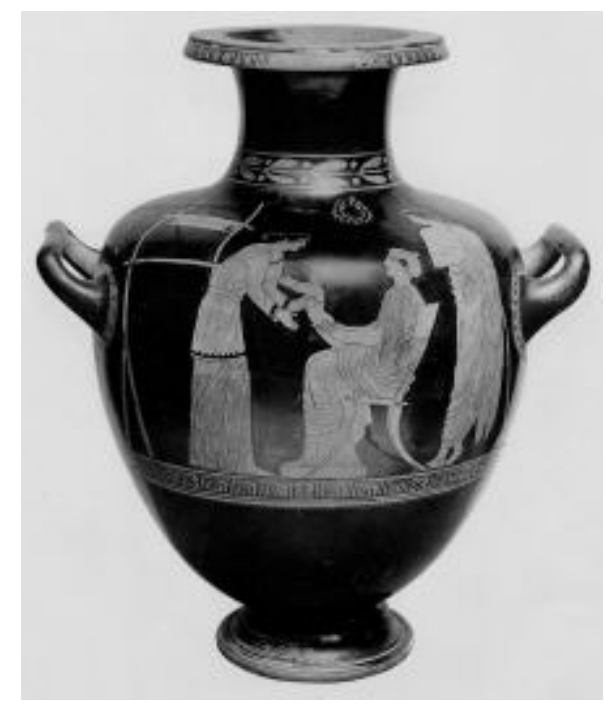

Localização: Coleção da Universidade de Havard (Robinson Collection III. 1), Temática: afeto materno, Proveniência: Vari, Forma: hýdria, Estilo: Figuras Vermelhas, Pintor: Polygnotan Circle, Data: 450-400 a.C., Indicação Bibliográfica: WILLIAMS, 1993, p. 93-94, fig. 7.2; LESSA, 2010, p. 60; FERREIRA, 2011, p. 78; www. beazley..ox.ac.uk/index.htm (vaso number 8184. Acesso em: outubro de 2020.

Nessa hýdria, temos quatro personagens. A comunicação estabelecida pelos personagens na imagem não está diretamente direcionada para o receptor externo - o público ateniense do século quinto ou mesmo nós no século atual -, mas apenas voltada para o âmbito interno da própria cena, demonstrando atenção a uma única ação: a transferência do recém-nascido do colo da mãe para o de uma ama.

Mais uma vez recorremos ao trabalho de Timothy McNiven (2007, p. 86-7). Nas imagens atenienses, os bebês apresentam gestos extremamente limitados, se comparados à figuração de crianças mais velhas e de adultos. Dentre os gestos infantis mais comuns nas imagens áticas, conta-se aquele da criança estendendo um ou ambos os braços em direção a outra pessoa como sinal de que quer ser pega. Essa hýdria apresenta uma cena certamente ambientada no gineceu, espaço típico de ação feminina, no qual poucos homens entravam (LISSARRAGUE, 1993, p. 241). Temos em cena uma personagem feminina que pode ser considerada uma esposa bem-nascida. Ela veste um chitón e um himátion de cores claras e plissados, seus pés estão descalços, seu cabelo está preso e 
envolto em um tecido, sua cor de pele é clara e ela aparece sentada numa cadeira de encosto elevado.

A presença do recém-nascido é outra característica que nos permite conceder a essa personagem feminina o status de esposa legítima e bem-nascida. Ela está sentada em uma cadeira no centro da cena, voltada para a esquerda, com os pés sobre um assento e entregando o seu filho para uma ama situada também à esquerda. $O$ recém-nascido usa um amuleto preso em um cordão, um símbolo apotropaico para afastar os males. Certamente, para tornar a vida o mais segura possível para os seus filhos, os pais sempre tinham o cuidado e usar os amuletos frequentemente. Segundo Klein (1932, p. 7), a corda que a criança carregava era pendurada em um dos ombros e cruzava o corpo de modo a ficar próximo ao quadril do outro lado. Prossegue ainda a autora, afirmando que a quantidade de amuletos em uma corda variava, mas parece que foi de 3 a 6 na maioria dos casos.

A preocupação dos helenos com as crianças revela o cuidado dos pais com o bem-estar dos filhos e a percepção de que a criança, sobretudo em idades iniciais, exige atenção especial (FERREIRA, 2010, p. 147).

Retornemos mais diretamente à imagem. A ama veste um chitón e uma túnica simples com mangas longas. As fitas de cores escuras que decoram a sua roupa podem ser uma indicação de escravidão. À direita, em pé, há um homem com poucos fios de barba na face, vestindo um himátion e inclinado sobre um bastão no qual sustenta sua mão direita. De acordo com Martin Robertson e Mary Beard (1993, p. 26), o bastão é um símbolo de poder, autoridade, exterioridade, portanto atributos que remetem ao espaço público. Enquanto para Williams (1993), esse homem é provavelmente o filho mais velho, a descrição do Corpus Vasorum Antiquorum (CVA) o concebe como o pai e, consequentemente, o esposo. Não podemos deixar de ressaltar a presença masculina no gineceu por ser algo considerado como incomum. Inclusive, podemos observar, como o fizeram Robertson e Beard (1993, p. 23), que a imagem masculina, quando representada em cenas de interior, normalmente excede o pescoço decorativo do vaso, o que pode fazer parecer que o homem seja grande demais para o espaço doméstico no qual está introduzido, isto é, o homem é visto como inadequado para este espaço. Na extrema esquerda, temos um tear. Esta representação nos fornece indícios acerca das obrigações básicas que competiam a uma esposa abastada, quais sejam: a procriação, a criação e educação dos filhos e a colaboração para a autossuficiência do grupo doméstico, tecendo 
roupas para o uso familiar e gerenciando os bens da casa (WILLIAMS, 1993, p. 94; LESSA, 2010, p. 60-1). ${ }^{21}$

A procriação e, principalmente, a criação e educação dos filhos, pelo menos nos seus primeiros anos de vida, foram vistas como fundamentais para uma esposa legítima. Essa inferência é resultante do fato de que a concepção de um filho significa a concretização do herdeiro, que será responsável pela manutenção do patrimônio, por cuidar dos pais na velhice, por realizar os funerais familiares e também por manter o culto doméstico. Reforçamos que a função dos filhos na Grécia antiga era prestar assistência aos mais velhos, aos pais em especial (FERREIRA, 2010, p. 147).

Quanto à criança presente em cena, constatamos que ela é do sexo masculino, sendo este detalhe de suma importância, pois o nascimento de um filho do sexo masculino, conforme já afirmamos, constitui uma clara indicação para o observador ateniense de que essa esposa havia cumprido sua obrigação para a reprodução da linha de cidadãos (ROBERTSON; BEARD, 1993, p. 24; LESSA, 2010, p. 63). ${ }^{22}$

Ainda quanto à figuração das crianças na imagética ática, podemos acrescentar que se elas não estivessem dormindo, poderiam ser vistas sentadas em seus berços, sella cacatoria, ${ }^{23}$ ou brincando ou ainda observando o que se passa no entorno (KLEIN, 1932, p. 4), conforme veremos nas próximas duas imagens que estudaremos.

\section{Imagens da infância: as crianças de Atenas}

As duas próximas imagens (Figuras 4 e 5) foram pintadas em duas choes e fazem referências ao cotidiano infantil, ao mundo dos brinquedos e dos jogos. As choes estão vinculadas às Anthestérias, festa realizada em honra a Dioniso e associada ao florescimento, simbolizando a passagem do inverno à primavera (LIMA, 2000, p. 92). As choes foram fabricadas em grande quantidade no último quartel do século $V$ a.C., sendo destinadas a servir o vinho. $O$ repertório que normalmente decorava uma chous era fixo: crianças a engatinhar nuas, portando amuletos ou sentadas na sella cacatoria; crianças mais velhas a brincar sozinhas ou acompanhadas; crianças com seus carrinhos ou animais de estimação, além de outras (FERREIRA, 2011, p. 79).

Passemos à primeira chous. Nela, temos representada uma criança ao centro, sentada numa cadeira-alta e portando um chocalho, além de uma enócoa (vaso para a

\footnotetext{
${ }^{21}$ De acordo com Williams (1993, p. 94), a roca se constituiu num símbolo literário de uma esposa bem-nascida, sendo isso apropriado pelos pintores, o que explica o fato de encontrarmos um número significativo de vasos cuja temática apresenta esposas fiando e tecendo.

${ }^{22} \mathrm{Cf}$. XENOFONTE. Econômico, VII, 12.

${ }^{23}$ Tipo de assento no qual a criança é encaixada, como o representado na figura 4.
} 
retirada do vinho da cratera) e um carrinho. A referência aos brinquedos e ao vinho nos remete diretamente às Anthestérias.

Figura 4 - Chous, sem autoria, datado de 450 a 400 a.C.

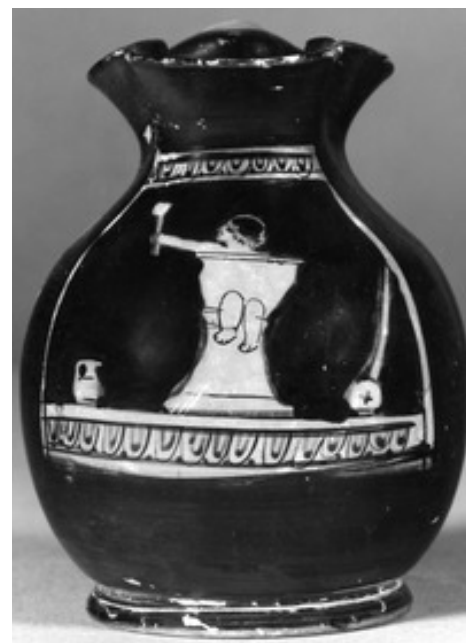

Localização: British Museum - inv. 1910.0615.4, Temática: brinquedos infantis, Proveniência: Atenas, Forma: chous, Estilo: Figuras Vermelhas, Pintor: não fornecido, Data: 450 a 400 a.C.; Indicação Bibliográfica: FERREIRA,

2011, fig. 2; www.beazley..ox.ac.uk/index.htm (vaso number 11041. Acesso em: outubro de 2020.

O espaço cênico é o interno, pois as crianças crescem no gineceu, onde escutam dos membros femininos da família canções e narrativas míticas; divertem-se com brinquedos ou animais domésticos e participam de festas religiosas, como as Anthestérias (MAFFRE, 1988, p. 148-9)..$^{24}$

No festival das Anthestérias, os meninos eram presenteados com uma coroa para usar na cabeça, um pequeno jarro conhecido como chous e um pequeno carrinho. Também era nessa ocasião que eles, pela primeira vez, experimentavam o vinho (GARLAND, 2009, p. 94). Dentre os brinquedos, predominavam os feitos em casa. Há evidências arqueológicas de miniaturas de cavalos com rodas, barcos, piões, chocalhos e bonecas com os membros móveis, além de bonecas e animais de pano (GARLAND, 2009, p. 95; FLACELIÈRE, 1988, p. 104). Acrescentemos também o ioiô.

A questão da produção dos brinquedos em casa pelas próprias crianças é atestada por Aristófanes, nas Nuvens (vv. 878-81). Este é um argumento de Estrepsíades para enaltecer o filho frente a Sócrates.

A imagem seguinte, pintada na segunda chous, repete o esquema cênico básico das cenas de crianças no âmbito das Anthestérias. Temos, no centro do vaso, um bebê

\footnotetext{
${ }^{24}$ A participação de crianças em cerimônias religiosas é anterior ao período clássico. Segundo Langdon (2008, p. 58), a presença de crianças nas cenas rituais da cerâmica geométrica é sinal de um mundo social no qual os jovens tiveram um adequado lugar na vida ritual da comunidade.
} 
engatinhando em direção ao carrinho que se encontra encostado na parede. A criança porta amuletos transpassados pelo dorso.

Figura 5 - Chous, sem autoria, datado de 450 a 400 a.C.

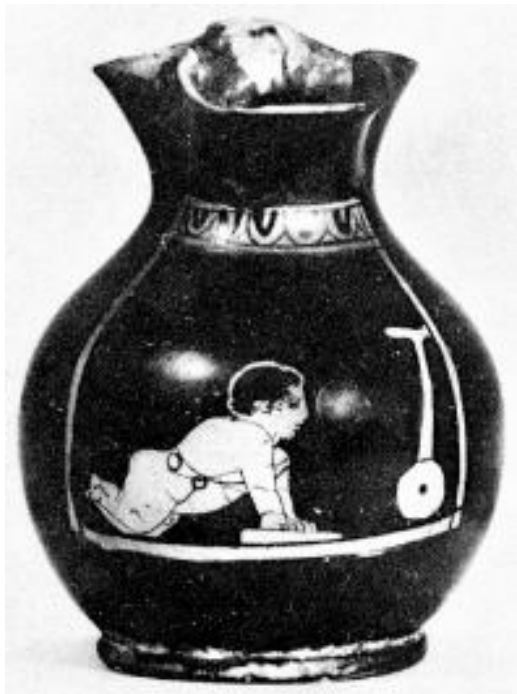

Localização: Antikensammlungen - inv. 2459, Temática: brinquedos infantis, Proveniência: não fornecido, Forma: chous, Estilo: Figuras Vermelhas, Pintor: não fornecido, Data: 450 a 400 a.C.; Indicação Bibliográfica: www.beazley..ox.ac.uk/index.htm (vaso number 11381. Acesso em: outubro de 2020.

A imagem corrobora o que falamos até o presente momento acerca da proteção das crianças com amuletos apotropaicos e de sua representação com um corpo diminuto, mas com feições mais adultas.

No que se refere aos jogos de olhares dos personagens, as cinco imagens que analisamos no presente texto trazem uma representação em perfil. De acordo com o método de análise iconográfica proposto por Claude Calame (1986, p. 101), a representação em perfil é o tipo mais comumente encontrado nos vasos do período clássico. A comunicação estabelecida pelos personagens nas imagens não está diretamente direcionada para o receptor externo, o público ateniense do período clássico ou mesmo nós, no século atual, mas apenas voltada para o âmbito interno da própria cena, demonstrando atenção às ações desenvolvidas. Logo, as cenas servem como exemplo a ser seguido pelos receptores.

\section{Conclusão}

Neste texto, buscamos apreender o espaço da infância na sociedade grega, no geral, e na ateniense, em particular, a partir de dois vieses, a saber: as relações de afeição desenvolvidas no gineceu pelos membros da família com as suas crianças e o processo de 
socialização infantil por intermédio da participação em jogos e brincadeiras. As imagens áticas de figuras vermelhas constituíram o corpus documental para a nossa análise.

Mesmo equiparando as crianças às mulheres e aos escravos, havia com frequência, por parte dos helenos, um cuidado com a primeira infância, pois é nítida a preocupação com o bem-estar dos filhos nessa faixa etária. Defendemos que tal preocupação excedia a ideia dos filhos legítimos como propiciadores da continuidade do grupo doméstico e da pólis. Ter abordado a infância por meio dos afetos familiares e da sua relação estreita com os membros femininos da família foi relevante para percebermos o quão importante era essa faixa etária na Atenas clássica. Podemos ainda acrescentar a importância dos filhos para o futuro amparo dos pais na velhice.

A educação (paideía) das crianças na fase inicial de suas vidas - até, pelo menos, os sete anos de idade - costumava ser responsabilidade das mães e parentes femininas, mas, por opção, apesar de sua relevância, não constituiu objeto de estudo neste artigo. A inserção social da criança na família acabou ganhando maior destaque no texto.

Por fim, estudar a infância ateniense não é um fim em si mesmo. Não teria sentido se as questões que foram fundamentais para a sociedade grega antiga não nos permitissem uma reflexão sobre o mundo contemporâneo e o Brasil, em especial. A situação de nossas crianças, muitas vezes relegadas à própria sorte nas ruas das várias cidades brasileiras, é algo que nos sensibiliza, principalmente diante de uma pandemia como a covid-19. Coincidentemente ou não, estamos refletindo sobre criança grega num ano em que o Estatuto da Criança e do Adolescente (ECA) completa 30 anos. O ECA corresponde a uma das primeiras legislações do mundo a adaptar os princípios da Convenção sobre os Direitos da Criança da ONU, ocorrida em 1989. Mais do que fazer de crianças e adolescentes brasileiros sujeitos do Direito, o ECA ainda precisa atuar no sentido de oferecer condições de sobrevivência e de educação que os transformem em verdadeiros cidadãos.

\section{Referências}

\section{Documentação textual}

ARISTÓFANES. As nuvens. As aves. As rãs. Tradução de Mário da Gama Kury. Rio de Janeiro: Zahar, 1996.

ARISTÓTELES. Ética a Eudemo. Tradução de Edson Bini. São Paulo: Edipro, 2015.

ARISTÓTELES. Política. Tradução de Mário da Gama Kury. Brasília: UnB, 1988.

ARISTÓTELES. Política. Tradução de António C. Amaral e Carlos C. Gomes. Lisboa: Vega, 1998. 
HERÓDOTO. Histórias: Livro I. Tradução de Maria Aparecida de Oliveira Silva. São Paulo: Edipro, 2015.

HOMERO. Odisseia. Tradução de Frederico Lourenço. São Paulo: Companhia das Letras, 2011.

HOMERO. Ilíada. Tradução de Frederico Lourenço. São Paulo: Companhia das Letras, 2013. PLATÃO. A República. Tradução de G. Guinsburg. São Paulo: Perspectiva, 2010.

XENOFONTE. Econômico. Tradução de Anna Lia A. A. Prado. São Paulo: Martins Fontes, 1999.

\section{Documentação visual}

CORPUS VASORUM ANTIQUORUM. Robinson Collection, III, 1, Plate XLIV. Disponível em: <https://www.beazley.ox.ac.uk/index.htm> e <https://www.britishmuseum.org/ collection/object>. Acesso em: 13/11/2020.

\section{Obras de referência}

BAILLY, A. Dictionnaire Grec-Français. Paris: Hachette, 2000.

BEEKES, R. Etymological dictionary of Greek. Leiden; Boston: Brill, 2010.

CHANTRAINE, P. Dictionaire étymologique de la langue grècque: histoire des mots. Paris: E. Klincksieck, 1983.

LIDDELL, H. G.; SCOTT'S, R. An intermediate Greek-English lexicon. Oxford: Clarendon Press, 1992.

MONTANARI, F. Vocabolario della lingua greca. Torino: Loescher, 2000.

\section{Obras de apoio}

ARIÈS, Ph. História Social da criança e da família. Rio de Janeiro: LTC, 2006.

ARIÈS, Ph. L'Enfant et la vie familiale sous l'Ancien Régime. Paris: Seuil, 1973.

BOURDIEU, P. A economia das trocas linguísticas. São Paulo: Edusp, 2008.

CALAME, $\mathrm{Cl}$. Le récit en Grèce Ancienne: enonciations et représentations de poètes. Paris: Meridiens Klincksieck, 1986.

CONDE, M. M. Las edades de la vida: infancia y vejez a través de la iconografía griega. In: IRIARTE, A.; FERREIRA, L. N. (coord.). Idades e gênero na literatura e na arte da Grécia antiga. Coimbra: Imprensa da Universidade de Coimbra, 2015, p. 31-60. 
DEBERT, A. G. A Antropologia e o estudo dos grupos e das categorias de idade. In: BARROS, M. M. L. (org.). Velhice ou Terceira Idade? Estudos antropológicos sobre identidade, memória e política. Rio de Janeiro: Editora da FGV, 2007, p. 49-58.

EDMUNDS, S. T. Homeric nēpios. London: Garland, 1990.

EISENSTADT, S. N. De geração a geração. São Paulo: Perspectiva, 1976.

FALKNER, T. M. The politics and the poetics of time in Solon's "Ten Ages". The Classical Journal, v. 86, n. 1, p. 1-15, 1990.

FERREIRA, L.N. A criança na Grécia antiga: concepções, normas e representações. In: FONSECA, C. F. (ed.). Crianças e adolescentes: uma abordagem multidisciplinar. Coimbra: Almedina, 2010, p. 137-172.

FERREIRA, L.N. A representação de crianças na arte grega. In: SOARES, C.; FIALHO, M. C.; MORÁN, M. C. A.; MONTIEL, R. M. I. (coord.). Norma \& transgressão II. Coimbra: Imprensa da Universidade de Coimbra, 2011, p. 59-96.

FLACELIÈRE, R. A vida quotidiana dos gregos na época de Péricles. Lisboa: Livros do Brasil, 1988.

FORBES, C. A. Neoi: a contribution to the study of Greek associations. Connecticut: The American Philological Association, 1933.

FORTES, M. Age, generation and social structure. In: KERTZER, D. I.; KEITH, J. (ed.). Age and anthropological theory. London: Cornell University Press, 1984, p. 99-122.

GARLAND, R. Daily life of the ancient Greek. Indianapolis: Hackett, 2009

GOLDEN, M. Children and childhood in Classical Athens. Baltimore: Johns Hopkins University Press, 1993.

GROPPO, L. A. Juventude: ensaios sobre sociologia e história das juventudes modernas. Rio de Janeiro: Difel, 2000.

IRWIN, M. W. Odysseus' "Hyacinthine Hair" in "Odyssey" 6.231. Phoenix, v. 44, n. 3, p. 20518, 1990.

JAEGER, W. Paidéia: a formação do homem grego. São Paulo: Martins Fontes, 2003.

JEANMAIRE, H. Couroietcourètes: essai surl'éducation spartiate et sur les rites d'adolescence dans l'Antiquité Hellénique. Lille: Bibliothèque Universitaire, 1939.

KLEIN, A. E. Child life in Greek Art. New York: Columbia University Press, 1932.

LACROIX, M. "H et ses élèves: en I'honneur de sa cinquantième année d'enseignement supérieur (1887-1937). Paris: Hachette, 1937, p. 261-272.

LANGDON, S. Art and identity in Dark Age Greece, 1100-700 B.C.E. New York: Cambridge University Press, 2008.

LESSA, F.S. Mulheres de Atenas: Mélissa do gineceu à agorá. Rio de Janeiro: Mauad X, 2010. 
LEVI, G.; SCHMITT, J-Cl. Introdução. In: (org.). História dos Jovens: da Antiguidade à

Era Moderna. São Paulo: Companhia das Letras, 1996, p. 7-17.

LIMA, A. C. C. Cultura popular em Atenas no V século a.C. Rio de Janeiro: Letras, 2000.

LISSARRAGUE, F. A Figuração das mulheres. In: DUBY, G.; PERROT, M. (org.). História das mulheres no Ocidente. Porto: Afrontamento, 1993. v. 1.

MAFFRE, J-P. A vida na Grécia clássica. Rio de Janeiro: Zahar, 1988.

MALINOWSKI, B. Crime e costume na sociedade selvagem. Brasília: Editora da UnB, 2008.

MALINOWSKI, B. The sexual life of savages in North Western Melanesia. New York: Eugenics, 1929.

MANNHEIM, K. Funções das gerações novas. In: PEREIRA, L.; FORACCHI, M. M. (org.). Educação e sociedade. São Paulo: Companhia Editora Nacional, 1976, p. 91-97.

MCNIVEN, T. J. Behaving like a child immature. In: COHEN, A.; RUTTER, J. B. (ed.). Construction of childhood in Ancient Greece and Italy. Athens: The American School of Classical Studies at Athens, 2007, p. 85-99.

MEAD, M. Adolescencia y cultura en Samoa. Barcelona: Paidós, 1990.

MEAD, M. Coming of age in Samoa. New York: William Morrow \& Company, 1928.

MORAES, A. S. Curso de vida e construção social das idades no mundo de Homero (séc. $X$ ao IX a.C.): uma análise sobre a formação dos habitus etários na Ilíada e Odisseia. Tese de doutorado apresentada ao Programa de Pós-graduação em História da Universidade Federal Fluminense. Niterói: UFF, 2013.

ROBERTSON, M.; BEARD, M. Adopting an approach. In: RASMUSSENT, T.; SPIVEY, N. (ed.). Looking at Greek vases. Cambridge: Cambridge University Press, 1993.

SAVAGE, J. A criação da juventude: como o conceito teenage revolucionou o século XX. São Paulo: Rocco, 2009.

SCHMITT PANTEL, P. Uma história pessoal: os mitos gregos. Coimbra: Imprensa da Universidade de Coimbra, 2019.

SCHNAPP, A. A imagem dos jovens na cidade grega. In: LEVI, G.; SCHMITT, J-Cl. (org.). História dos jovens: da Antiguidade à Era Moderna. São Paulo: Companhia das Letras, 1996, p. 19-57.

SOARES, C. Crianças jovens nas 'Vidas' de Plutarco. Coimbra: CECH, 2011.

VERNANT, J-P. A morte nos olhos: figuração do outro na Grécia antiga, Ártemis e Gorgó. Rio de Janeiro: Zahar, 1991.

WILLIAMS, D. Women on Athenian vases: problems of interpretation. In: CAMERON, A.; KUHRT, A. (ed.). Images of women in Antiquity. London: Croom Helm, 1993, p. 92106.

Romanitas - Revista de Estudos Grecolatinos, n. 16, p. 61-80, 2020. ISSN: 2318-9304. 